\title{
Unge retorar i Lofoten: Ein Toulmin-inspirert argumentasjonsanalyse av ein klasseromsdebatt
}

Tidsskriftet Sakprosa

Bind 10, Nummer 3

(C) 2018 


\section{Samandrag}

Emnet for denne artikkelen er ungdomskulelevars argumentasjonskompetanse, slik denne kjem fram i ein klasseromsdebatt om oljeutvinning i Lofoten-området. Klasseromsdebatten var førebudd via gruppearbeid der elevane tok utgangspunkt i tre ulike scenario om oljeutvinning i Lofotenområdet. Det sentrale forskingsspørsmålet i artikkelen er kva argumentasjonskompetanse elevane syner i form av å byggje resonnement saman. Den analytiske tilnærminga er ein argumentasjonsanalyse med utgangspunkt i Toulmins argumentasjonsmodell (Toulmin 2003 [1958]). Kva potensial Toulmin-modellen har som analysereiskap av dialogisk argumentasjon, er også eit forskingsspørsmål i artikkelen.

Analysen syner at elevane som deltok i denne klasseromsdebatten saman forma eit koherent hovudresonnement med ein tydeleg mot-argumentasjon. Analyseresultata tyder på at elevar i 8. klasse er i stand til å forme ganske komplekse resonnement saman, men at dette føreset god didaktisk tilrettelegging. Resultata viser også at Toulmin-modellen er eigna til å beskrive aktiv debatt blant elevar i ein klasseromssituasjon, og at modellen let seg integrere i eit dialogisk perspektiv på undervisning og språkleg samhandling.

\section{Abstract}

This article offers an analysis of a classroom debate on oil exploitation from a lower secondary school in Lofoten, Norway. The students discuss potential oil exploitation close to their hometown. Prior to the debate scenario-based tools were used to catalyse discussion. The main research question in the article is which arguing skills these students show by constructing arguments together. The classroom debate is analyzed by identifying the main argument using the Toulmin argument model (Toulmin 2003 [1958]). To which degree the 
Toulmin model is an appropriate analytical tool in order to analyse dialogical argumentation is also a research question addressed in this article.

The analysis shows that the students constructed a coherent main argument including a substantial counter argument together. The results suggest that students in $8^{\text {th }}$ grade are capable of building quite complex arguments together, if necessary didactical facilitation is in place. Furthermore, the Toulmin model turned out to be a useful way to analyse the way the students argued in this debate, and seemed to integrate well in a dialogical approach.

Nøkkelord: argumentasjon, Toulmin-modellen, munnleg-didaktikk, demokratisk danning

\section{Om forfattaren:}

Kjersti Maria Rongen Breivega er førsteamanuensis i norsk ved Institutt for språk, litteratur, matematikk og tolking ved Høgskulen på Vestlandet. 


\section{Unge retorar i Lofoten: Ein Toulmin-inspirert argumentasjonsanalyse av ein klasseromsdebatt}

\section{Innleiing}

Ved ein ungdomskule i Lofoten-området vart to 8. klassar i juni 2013 stilte overfor ein uvanleg retorisk situasjon då ei forskargruppe utfordra elevane til debatt om eventuell oljeutvinning i nærområda deira. Resultatet vart ein 100 minuttar lang klasseromsdebatt, der mange elevar var aktive deltakarar (frå no: Lofoten-debatten). Som forskingsmateriale representerer Lofotendebatten eit sjeldan eksempel på elevar som er aktive i debattsjangeren, noko som er av interesse både for elevars munnlege og retoriske kompetanse (Aksnes 2016, Hertzberg 2016 og Bakken 2014) og i eit demokratipedagogisk perspektiv (Englund 2007, Hess 2009, Brumark 2011 og Berge \& Stray 2012). Sistnemnde perspektiv synest stadig meir vektlagt i norsk skule og utdanningssektor, og i den revideringa som no går føre seg av den norske læreplanen, er demokrati og medborgarskap eitt av tre gjennomgåande tema for alle fag (Utdanningsdirektoratet 2017).

Lofoten-debatten inngår i det tverrfaglege forskingsprosjektet Kritisk demokratisk danning (Lived Democracy) ved Høgskulen på Vestlandet, og var initiert og gjennomført av forskarar i dette prosjektet. Dette forskingsprosjektet har som overordna mål å dokumentere og beskrive norske skuleelevars demokratiske kompetanse og praksis, og å fremje demokratisk danning (Breivega, Hauge, Johnsen-Høines \& Rangnes 2016).

Det overordna empiriske forskingsspørsmålet i denne artikkelen er kva argumentasjonskompetanse elevane i Lofoten-debatten syner i form av å byggje resonnement saman. Er elevytringane resonnementsmessig relaterte til kvarandre, slik at ein kan sjå dei som responsar på tidlegare formulerte påstandar, eller framstår dei snarare som meir lausrivne, 
assosiative innspel til eit overordna tema? Den analytiske tilnærminga vil vere ein argumentasjonsanalyse med utgangspunkt i Toulmins argumentasjonsmodell (Toulmin 2003 [1958]). Denne modellen fokuserer på innhaldssida ved argumentasjon; dvs. kva påstandar som vert ytra og korleis dei er relaterte til kvarandre. Ei ofte brukt innvending mot Toulmin-modellen, er at modellen er for monologisk til å fange opp dialogisk argumentasjon og autentisk språkleg samhandling føremålstenleg (Simosi 2003, Nielsen 2013). For å bruke denne modellen i analyse av ein fleirstemmig klasseromsdebatt, har det difor vore naudsynt å gjere tilpassingar i den analytiske tilnærminga, og kva potensial Toulmin-modellen har som analysereiskap i munnleg-didaktisk forsking, vil også vere eit forskingsspørsmål denne artikkelen borar i.

\section{Perspektiv på klasseromsdebatt}

Klassromsdebattar har eit stort potensial i opplæringa, både med tanke på å ruste elevar til demokratisk deltaking og i eit munnleg-didaktisk perspektiv: to perspektiv som sjølvsagt heng tett saman. I eit demokratipedagogisk perspektiv er klasseromsdebatt framheva som ein viktig arena for deliberasjon og meiningsbryting (Englund 2007) i det usemjefellesskapet eit klasserom representerer (Iversen 2014). Det vert også vektlagt at diskusjonar om kontroversielle og autentiske emne fremjar læring av fagstoff, kritisk tenking og utviklar eleven si evne til å respektere ulikskap og meiningsmangfald (Hess 2009, s. 29).

I læreplanverket Kunnskapsløftet (LKo6) er munnlege ferdigheiter ei av fem grunnleggjande ferdigheiter i alle fag (Kunnskapsdepartementet 2006). Munnlegheit er sterkt vektlagt i gjeldande læreplan, og ulike former for diskusjonar er sjangrar som er framheva i fleire fag (norsk, samfunnsfag og naturfag). Klasseromsdebatt er likevel ein sjanger som synest å vere lite i bruk i norsk skulekvardag. Nyare forsking frå ungdomssteget viser at det er skeivfordeling av den tida og dei ressursane som vert brukte på ulike munnlege 
sjangrar. I norskfaget er framføringa den dominerande sjangeren. Debatt og diskusjon, på si side, tek liten plass, berre $1 \%$ av den totale klasseromsaktiviteten (Svenkerud, Klette og Hertzberg 2012, s. 40). I så måte representerer Lofoten-debatten eit unikt datamateriale.

Både tekstforskinga og didaktikken står i dag i eit diskursivt og dialogisk paradigme (Bakhtin 1998, Skaftun 2009, Dysthe 1995). All språkbruk er situert og går føre seg i ein kontekst som i seg sjølv er konstituerande for det som vert kommunisert. All tekst er fleirstemmig og heterogen og handlar djupast sett om samhandling med andre. I eit slikt perspektiv er monologiske og u-situerte tilnærmingar til tekst og kommunikasjon mindre fruktbare. I eit didaktisk perspektiv taler ein gjerne om dialogisk undervisning (Alexander 2005). Elevar lærer best via språkleg samhandling med andre, og læraren må leggje til rette for at klasserommet vert ein arena der dette kan skje, både i diskusjonar og via andre læringsaktivitetar. I Lofoten-debatten er det ikkje ein lærar, men ein forskar, som er samtaleleiar, og for henne gjeld dei same pedagogiske prinsippa: ein god samtaleleiar stiller autentiske spørsmål, gjer opptak (repeterer det elevane seier) og viser generelt høg verdsetting ved f.eks. å tole innvendingar frå elevane (Børresen 2016, s. 96). Ifølgje Alexander er den gode, læringsfremjande samtalen prega av å vere m.a. gjensidig (elevar og lærarar lyttar til kvarandre og vurderer saman alternative måtar å tenkje på) og kumulativ (elevane byggjer vidare på det andre seier) (Alexander 2005, s. 34). Den metodiske tilnærminga til debatten som vert gjort i denne artikkelen representerer eit forsøk på å integrere desse dialogiske perspektiva i ein argumentasjonsanalyse. 


\section{Bakgrunn for Lofoten-debatten}

Oljeboring i Lofoten-området

Heilt sidan slutten av 1970-talet har det stått strid om oljeboring i nord. Først gjaldt det opning av områda nord for 62. breiddegrad, og frå midten av 1990talet fekk spørsmålet om havområda utanfor Lofoten, Vesterålen og Senja stor merksemd.

Tilhengjarane av oljeutvinning i Lofoten-området argumenterer først og fremst med at oljeverksemd vil føre til arbeidsplassar, tilflytting og generell økonomisk vekst, i dette tilfellet i område som elles er prega av svak vekst, økonomisk og demografisk. Dei legg også vekt på at oljeverksemda no har nådd eit tryggleiksnivå som gjer alvorlege ulykker og store utslepp lite sannsynleg. Motstandarane av oljeboring legg i sin argumentasjon hovudvekta på miljøvern og framhevar kor alvorlege konsekvensane av eit eventuelt utslepp kan vere. Lofotfisket er det viktigaste sesongfisket på torsk i Noreg, og det er stor risiko for skade på gyteområda til fisken ved eit eventuelt utslepp. Eventuelle utslepp vil dessutan ikkje berre øydeleggje naturen, men også svekkje turistnæringa, som er like viktig for regionen som fisket. Fleire av motstandarane arbeider også for ein søknad om å gjere Lofoten til eit verdsarvstad på UNESCO-lista (Sande 2013, Ryggvik \& Sander 2017).

\section{Gjennomføring av debatten}

Lofoten-debatten vart gjennomført av forskarar frå prosjektet Kritisk demokratisk danning. ${ }^{1}$ Forskargruppa fekk løyve til å gjennomføre ein debatt

\footnotetext{
${ }^{1}$ Forskarane som deltok i planlegging og gjennomføring av Lofoten-debatten var Kjellrun Hiis Hauge, Marit Johnsen-Høines, Tobias C. Werler, Peter Gøtze og Signe Wågan Rørmark.
} 
om oljeutvinning med 50 elevar frå to 8. klassar ved ein lokal ungdomskule. Lærarane vart inviterte til å vere med, men valde å ikkje delta. Lofotendebatten er altså ikkje ein del av elevane si ordinære undervisning.

Av lærarane fekk forskarane opplyst at elevane ikkje hadde arbeidd spesifikt med oljeutvinning som tema, men at dei nyleg hadde gjennomført eit prosjektarbeid der dei undersøkte korleis lokale bedrifter stilte seg til berekraftig utvikling. Som ein del av dette prosjektarbeidet hadde elevane skrive refleksjonsnotat som forskarane fekk lese. Forskargruppa fekk dessutan møte elevane ein times tid dagen før debatten og samtalte då gruppevis med dei med utgangspunkt i refleksjonsnotata.

I og med at lærarane ikkje deltok, måtte forskargruppa på ei og same tid leggje til rette for eit undervisningsopplegg og datainnsamlinga i eit forskingsprosjekt. Det var valt ei scenariobasert tilnærming (Pereira 2001, s. 9). Eit scenario tek utgangspunkt i ei autentisk problemstilling og beskriv mogelege, framtidige løysingar. Sjølve debattdagen starta med eit gruppearbeid der elevane vart presenterte for desse tre scenarioa om oljeboring i Lofoten:

\begin{tabular}{|l|l|}
\hline A & $\begin{array}{l}\text { Det skal borast for fullt etter olje utanfor Lofoten } \\
\text { B }\end{array}$ \\
$\begin{array}{l}\text { Ein skal byggje ut litt etter litt, og ventar med å bestemme om større område } \\
\text { skal ha oljeboring }\end{array}$ \\
\hline C & Lofoten skal stengjast for oljeboring \\
\hline
\end{tabular}

Tabell 1 
I gruppearbeidet vart elevane delte inn i grupper på 4-6 elevar, og kvar gruppe fekk tildelt eitt scenario som dei skulle utvikle argumentasjon rundt. Instruksjonane elevane fekk om å utvikle argumentasjon var generelle, og ikkje kopla opp mot Toulmin-modellen eller andre rammeverk. Kvart scenario vart presentert på eit ark der det var formulert nøkkelord frå den offentlege debatten om oljeutvinning i Lofoten-området som fiske, økonomi, natur og kultur. Elevane skreiv argumenta sine på "trafikk-lys-kort”, der raudt lys indikerte at argumentet var i mot scenariet og grønt at det var for scenariet. Det gule lyset indikerte usikkerheit.

Både det førebuande gruppearbeidet og sjølve debatten vart leia av ein av forskarane («Forsker 1»). «Forsker 1» er matematikkdidaktikar og tidlegare havforskar, og i innleiinga til gruppearbeida gjorde ho greie for korleis oljeutvinning går føre seg og svarte å konkrete spørsmål om kva f.eks. ein oljebrønn eller eit korallrev er for noko. Ein annan forskar («Forsker 2») deltok også i samtalen, både under gruppearbeida og plenumsdebatten, medan dei andre forskarane videofilma debatten. Elevane vart instruerte om at debatten skulle vere som ein TV-debatt, og ikkje ein slik debatt dei var vane med å ha på skulen. Elevane reiste seg under innlegga sine, og dei som ønskte det, brukte handhalden mikrofon. Kommunikasjonssituasjonen var slik relativt formell. I ettertid er opptaka av debatten transkriberte verbatim (ord for ord) til normert bokmål. Alle dei 383 replikkane er nummererte, og identifiserte elevaktørar er tildelte fiktive namn. Stadnamn er også anonymiserte.

\section{Toulmin-modellen som metodisk grep}

Presentasjon av modellen

Det er mange måtar å nærme seg fenomenet argumentasjon på. Toulminmodellen, som skal leggjast til grunn her, representerer ei resonnements- 
tilnærming til argumentasjon. Logikaren Stephen E. Toulmin lanserte denne modellen i boka The Uses of Argument i 1958, og modellen har fătt ein solid posisjon innan argumentasjonsteori -og analyse (van Eemeren, Garssen, Krabbe, Henkemans, Verheij \& Wagemans 2014; Brodersen, Bråten, Reiersgaard, Slethei, \& Ågotnes 2007, Jørgensen \& Villadsen 2009, Jørgensen \& Onsberg 2011 og Kjeldsen 2014).

Ifølgje Toulmin er eit resonnement (an argument) ein logisk struktur der påstandar interagerer for å støtte opp om ein (hovud)påstand (claim) (Toulmin 2003, s. 87ff). Modellen består av seks komponentar: hovudpåstand (claim), belegg (data), heimel (warrant), styrkemarkør (qualifier), ryggdekning (backing) og innvending (rebuttal). Hovudpåstanden er den viktigaste påstanden i resonnementet; det er den påstanden resonnementet som heilskap stør opp om. Belegget er ein påstand som stør påstanden direkte, og som korresponderer med det som i allmennspråket ofte vert omtala som argument. Heimelen er ikkje ein påstand som stør hovudpåstanden direkte, men har ein brubyggjarfunksjon ved å formulere ein premiss som gjer det mogeleg å trekkje slutningar frå belegg til hovudpåstand. Hovudpåstand, belegg og heimel er dei obligatoriske kjernekomponentane i resonnementet, ofte omtalt som grunnmodellen (Jørgensen \& Onsberg 2011, s. 16). I tillegg kan eit resonnement ha tre komponentar til (utvida modell). Dette dreier seg om styrkemarkør, ryggdekning, og sist, men ikkje minst, innvending. Nedanfor er alle seks komponentane viste via av eitt av Toulmins eigne eksempel: ${ }^{2}$

\footnotetext{
2 I all hovudsak er terminologien som er i bruk her i tråd med det som er vanleg praksis i norske og danske omsetjingar, slik ein møter den hos m.a. Grepstad 1997 (s. 170-171) og i Jørgensen \& Onsberg 2011. Dette gjeld m.a. termane belegg og heimel, som er innarbeidde ekvivalentar for data (ground) og warrant. Den direkte, og mest vanlege, omsetjinga av claim er elles påstand, men dette er eigna til å forvirre, då alle komponentane i Toulmin-modellen (med unntak av styrkemarkøren) nettopp er påstandar. Difor er hovudpåstand (eventuelt hovudsynspunkt eller standpunkt) å føretrekkje. Toulmins term for den overordna påstandsstrukturen, argument, ser ein ofte i bruk i skandinaviske språk, men resonnement (jf. Brodersen mfl. 2007, s. 29) er her å føretrekkje, for å unngå samanblanding med
} 


\begin{tabular}{|c|c|}
\hline Belegg & «Harry was born in Bermuda» \\
\hline Styrkemarkør & So, «presumably» \\
\hline Hovudpåstand & «Harry is a British subject» \\
\hline Heimel & $\begin{array}{l}\text { Since «A man born in Bermuda will generally be a } \\
\text { British subject» }\end{array}$ \\
\hline Ryggdekning & $\begin{array}{l}\text { On account of «The following statues and other legal } \\
\text { provisions» }\end{array}$ \\
\hline Innvending & $\begin{array}{l}\text { Unless «Both his parents were aliens/he has become a } \\
\text { naturalized American.» (Toulmin 2003, s. 97) }\end{array}$ \\
\hline
\end{tabular}

Tabell 2

argument i allmennspråkleg tyding (= belegg). Når det gjeld dei tre komponentane som kjem i tillegg til grunnmodellen, synest ryggdekning å vere ei særs stabil omsetjing av backing, medan det er ganske stor variasjon i omsetjinga av qualifier og rebuttal. Både Grepstad og Jørgensen \& Onsberg omtaler qualifier som styrkemarkør, slik eg har valt å gjere her, men Brodersen mfl. bruker forbehold (Brodersen mfl. 2007, s. 36) og Bjørhusdal atterhald (Bjørhusdal 2014, s. 96). Styrkemarkør, eventuelt rett og slett kvalifisering, synest mest korrekt, då dette dreier seg om epistemiske kvalifiseringar som plasserer seg ulike stader på aksen sann/sikker-usikker/usann (jamfør Toulmin 2003, s. 36). Det dreier seg altså ikkje berre om å signalisere usikkerheit. I dansk og norsk bokmål er gjendrivelse/gjendriving ei innarbeidd omsetjing av rebuttal, men i nynorsk språkdrakt er ikkje dette noka god løysing. Det gode nynorskordet atterhald er m.a. brukt av Grepstad (1997, s. 171), men problemet med denne termen er at han peiker mot ei epistemisk kvalifisering som signaliserer usikkerheit, medan «rebuttal» i Toulmins modell er ei meir substansiell innvending i argumentasjonen. Difor er rett og slett innvending valt som omsetjing av «rebuttal» her (sjå også Brodersen mfl. 2007, s. 36). 
Eksempelet viser korleis belegget og heimelen representerer ulike former for grunngjeving av hovudpåstanden. Belegget representerer ei direkte grunngjeving, ofte i form av ei faktaopplysning som den vi ser her, medan heimelen er ein meir generell påstand (premiss) som ein byggjer argumentasjonen sin på (her signalisert via «generally»). Heimelen er rekna som noko av det mest originale i Toulmin-modellen. Heimelen representerer «underlaget» for resonnementet, dvs. verdiar, ideologiar og «tatt for gitt»praksisar som den som ytrar seg, legg til grunn. Samstundes er det slik at heimelen ofte er underforstått i argumentasjonen, og altså ikkje eksplisitt uttrykt. Vidare har ryggdekninga i resonnementet som funksjon å underbyggje heimelen, og som vi ser i eksempelet, skjer dette typisk i form av meir konkrete faktapåstandar lik dei vi finn i belegga (Toulmin 2003, s. 98). Innvendinga nemner omstende der heimelen ikkje vil gjelde og resonnementet som heilskap vert svekt. Styrkemarkøren (her: «presumably») er ord og frasar som signaliserer styrken i resonnementet. Heile resonnementet er bygd på inferensar, og desse kan vere eksplisitt signaliserte via tekstbindarar som «so» og «since», slik vi ser i eksempelet.

Det er viktig å merke seg at dei resonnementa Toulmin interesserer seg for er substansielle, og ikkje analytiske. I analytiske resonnement i den strengt logiske tradisjonen følgjer konklusjonen direkte av premissane. I substansielle resonnement følgjer ikkje konklusjonen med nødvendigheit av premissane (Toulmin 2003, s. 116f), og det vil alltid vere rom for tvil og motargumentasjon. Slik representerer Toulmin-modellen ein reiskap for å analysere realistisk og autentisk argumentasjon frå alle livs- og språkbrukssfærar, jamvel frå dagleglivet og sjølvsagt også frå klasserommet.

Det er likevel noko heilt anna å anvende denne modellen i møte med autentisk språkleg samhandling enn det er å illustrere han via Toulmins konstruerte eksempel. I praktisk argumentasjon av ein viss kompleksitet, anten denne er ytra av eitt talande subjekt eller fleire, vil ein finne svært mange påstandar, og 
det er inga endefram oppgåve å identifisere kva komponentar i Toulminskjemaet dei ulike påstandane representerer. Det er ingen formelle og grammatiske kjenneteikn ved dei ulike komponentane. Kva som fungerer som eit belegg eller ein heimel er eit spørsmål om funksjon i ein gjeven kontekst. Den tolkinga vi gjer av eit resonnement vil difor alltid kvile på situasjonsspesifikke informasjonar og førestillingar, og Toulmin har vorte kritisert for ikkje i tilstrekkeleg grad å klargjere dette (Simosi 2003, Nielsen 2013, Øgreid 2017).

Det som i tillegg gjer ein Toulmin-analyse krevjande, er at ikkje alle komponentar treng vere realiserte i alle resonnement. Som alt nemnt, må heimelen ofte infererast, men jamvel belegg og hovudpåstandar kan vere underforståtte (Jørgensen \& Onsberg 2011, s. 21). I eit autentisk språkleg materiale av ein viss kompleksitet vil det også vere slik at argumentasjonen, på eit overordna plan, kan vere strukturert på ulike måtar. På den eine sida kan vi finne store, utbygde resonnement, der ein og same hovudpåstand er støtta av fleire belegg, heimlar og eventuelle ryggdekningar. På den andre sida kan argumentasjonen vere ordna meir hierarkisk, slik at det som er belegget for ein hovudpåstand i sin tur vert den påstanden det vert argumentert for. Desse to struktureringsprinsippa vert ofte omtalte som respektive argumentrekkje og argumenthierarki (Kjeldsen 2014, s.184-185; Jørgensen \& Onsberg 2011, s. 30-31).

I norsk samanheng har Toulmin-modellen vore mykje brukt i opplæringa i akademisk skriving (Brodersen, Bråten, Reiersgaard, Slethei \& Ågotnes 2007), og i både skandinavisk og internasjonal samanheng synest modellen å ha ein solid posisjon innan realfagsdidaktisk forsking (Nielsen 2013). Innan didaktisk forsking med utspring i språk- og kulturfaga har modellen vore mindre brukt, men to ferske norske bidrag, som også eksemplifiserer ulike tilpassingar av modellen, er Øgreid 2017 og Myklebust \& Høisæter 2018. Begge desse arbeida er analysar av skrivne elevtekstar. 
Framgangsmåte i denne analysen

Eit punkt som er av særleg relevans for den føreliggjande studien, er at Toulmin-modellen er kritisert for å einsidig fokusere på argumentasjon som produkt og slik misse av syne dei dialogiske sidene ved argumentasjon, slik argumentasjon utfaldar seg som ein aktivitet, ein prosess (Nielsen 2013). Ein klassisk Toulmin-analyse er monologisk i den forstand at han fokuserer på korleis ulike komponentar interagerer for å støtte opp om éin hovudpåstand, normalt ytra av berre eitt utseiande subjekt. Brukt på ein klasseromsdiskusjon som den vi skal sjå på her, kunne ein da kome til å rekonstruere resonnement i ein munnleg diskusjon med mange deltakarar som eit upersonleg og tidlaust destillat, der kven som sa kva og i kva rekkjefølgje, er heilt usynleggjort (Nielsen 2013, s. 374-375), noko som sjølvsagt ville vere ein utilfredsstillande måte å nærme seg dialogisk argumentasjon på.

I denne artikkelen skal Toulmin-modellen brukast for å undersøke korleis 8. klassingar byggjer resonnement saman i ein debatt. Det er sjølvsagt mange måtar dette kunne vore gjennomført på. Ein kunne valt ut ein mindre sekvens av debatten og analysert denne i detalj, og då gjerne med utgangspunkt i alle komponentane i Toulmin-modellen. Eller ein kunne følgd nokre få elevar gjennom heile debatten og undersøkt deira resonnement nærare, f.eks. kunne ein jamført belegg og heimlar hos elevar som syntest å argumentere for ulike framtidige scenario. Målet med denne analysen er, som nemnt i innleiinga, å etablere ei meir overordna lesing av debatten ved å undersøke korleis elevytringane resonnementsmessig er relaterte til kvarandre. Difor vil analysen prøve å fange inn så store delar av debatten som mogeleg.

I og med at det empiriske forskingsspørsmålet her er kva argumentasjonskompetanse elevane syner i form av å byggje resonnement saman, er det ikkje den einskilde eleven sine resonnement som skal identifiserast, men dei elevane saman etablerer. Den teksten klasseromsdebatten utgjer vert difor her 
behandla som éi kollektiv talehandling. Analysen vil likevel, på ein tydeleg måte, vise fram kven som seier kva og på kva måte. Ikkje minst vil analysen følgje debatten som argumentativ prosess, slik han utfalda i tidsrekkjefølgje. Komponentane i resonnementsanalysen vil altså bli presenterte i kronologisk rekkjefølgje, og samspelet mellom elevane og debattleiaren vil slik kome fram. Dei komponentane frå Toulmin-skjemaet som vil inngå i denne analysen er hovudpåstandar, belegg, heimlar og innvendingar3, og sistnemnde kategori er avgjerande for å ivareta det dialogiske perspektivet.

Eit hovudgrep i den analytiske tilnærminga her er nemleg den tilpassinga som vert gjort av den mest dialektiske komponenten i Toulmin-skjemaet, innvendinga. Innvendinga (the rebuttal) er i monologisk bruk av Toulminmodellen mot-argument som den som argumenterer for noko sjølv nemner og gjerne imøtegår. I denne analysen vil innvendingane vere mot-påstandar (andre) elevar formulerer til påstandar og synsmåtar som er fremja i debatten.

Sidan målet med analysen er å etablere ei overordna lesing og undersøke korleis elevar byggjer resonnement saman, vil lesemåten vere argumentrekkja framfor argumenthierarkiet. Vidare er analysen sjølvsagt ikkje føresetnadslaus; han har ei kontekstuell innramming. Viktige premissar for lesinga er den bakgrunnsinformasjonen som er gjeven over, både det som gjeld det offentlege ordskiftet kring oljeboring i Lofoten og den spesifikke innramminga forskar-temaet frå Bergen gav debatten, m.a. via scenariobasert pedagogikk. Dei tre scenarioa (scenario A, B og C) representerer ei særleg

\footnotetext{
3 Styrkemark $\phi r$ og ryggdekning inngår dermed ikkje. Styrkemarkøren er i seg sjølv ikkje ein påstand, men ord og frasar som kvalifiserer påstandar. Fokuset i denne analysen er innhaldsbasert, på påstandane som vert fremja og ikkje på korleis dei vert styrkte eller svekte via den typen signal strykemarkørar representerer. For ein analyse av elevane si diskursive posisjonering i denne debatten, sjå Breivega (under utgjeving). Ryggdekningar, som altså er ytterlegare argumentasjon for heimlane, syntest som ein avansert kategori i møte med dette materialet.
} 
sentral forståingsramme for analysen av overordna resonnement i form av argumentrekkjer i dette materialet.

\section{Analyse}

Debatten har ei naturleg tredeling på grunn av to avvikla friminutt (etter replikk 156 og etter replikk 277). Starten og slutten på debatten var dessutan innleiande og avsluttande samtale utan aktiv debatt. Vi går inn i der debatten startar ved at debattleiaren (Forsker 1) utfordrar eleven Tom til å dele nokre argument.

$<38>$ Tom: Ja, vi har da scenario A. Vi er for full oljeboring i Lofoten. Det økonomiske, det er økonomisk, bærekraftig utvikling - flere jobbmuligheter, det vil si mer inntekter. Og det er jo sånn at desto mer oljeboring det blir her i Lofoten, jo mer folk og innbyggere kommer det. Da må vi bygge ut. Og det vil også koste penger, derfor får vi inntektene. Og ja, det er - ja

$<39>$ Forsker 1: Flott! Er det noen som har støttet dette, eller som har argumenter imot på akkurat disse temaene, for dette var jo flere temaer. Har dere noe som ligner her, eller er helt motsatt?

I replikk 38 vert det fremja eit tydeleg syn om oljeboring i Lofoten, og det vert presentert fleire argument som stør oppunder denne synsmåten. Ifølgje Toulmins terminologi har vi då ein hovudpåstand og fleire belegg. Alle belegga har same innretning, dei handlar om økonomisk vekst i form av arbeidsplassar, inntekter og tilflytting (belegg 1-3). Dermed er dei også heimla på same måte, i form av ei vektlegging av økonomisk vekst som eit viktig gode (heimel 1). Denne heimelen er elles halvvegs direkte uttrykt i starten av replikken («Det økonomiske, det er økonomisk, bærekraftig utvikling - »). 


\begin{tabular}{|l|l|}
\hline Hovudpåstand 1 & $\begin{array}{l}\text { Det bør bli full oljeutvinning i Lofoten- } \\
\text { området }\end{array}$ \\
\hline Belegg 1 & Oljeutvinning vil gje arbeidsplassar \\
\hline Belegg 2 & Oljeutvinning vil gje tilflytting \\
\hline Belegg 3 & Oljeutvinning vil gje inntekter \\
\hline Heimel 1 & Okonomisk vekst er eit gode \\
\hline
\end{tabular}

Tabell 3

I replikk 39 ser vi korleis debattleiaren svarer entusiastisk på Toms innspel og spør om det er andre som stør dette eller om det er andre som har motargument. Roy reiser seg og seier at hans gruppe også har scenario A, men grunngjev det annleis:

<46>Roy: Vi har også scenario A. Og vi har kommet frem til at det også vil bli økt beredskap mot oljeutslipp.

Debattleiaren går i dialog med Roy for å få han til å forklare nærare kva som ligg i denne argumentasjonen. Roy stadfestar at han ikkje berre tenkjer på den risikoen for oljeutslepp som oljeverksemda i seg sjølv vil føre med seg, men også «på andre ting enn oljeboring» som at ein båt kan gå på land. Her dukkar det dermed opp eit nytt belegg (belegg 4) og ei ny heimling (heimel 2). Heimel 2 er inferert. Heimelen er eit typisk eksempel på ein heimel som er under- 
forstått, og altså ikkje eksplisitt uttrykt av den som talar, kanskje fordi det synest så opplagt at auka beredskap er eit gode?

\begin{tabular}{|l|l|}
\hline Hovudpåstand 1 & $\begin{array}{l}\text { Det bør bli full oljeutvinning i Lofoten- } \\
\text { området }\end{array}$ \\
\hline Belegg 4 & Oljeutvinning vil føre til auka beredskap \\
\hline Heimel 2 & Auka beredskap er eit gode \\
\hline
\end{tabular}

Tabell 4

Debattleiaren oppsummerer og verdset Roys resonnement, men slepper så denne tråden og vil ha elevane til å kome med fleire argument knytt til arbeidsplassar. Det gjer Eva:

$<52>$ Eva: Det blir arbeidsplasser, men til slutt blir vi jo tom for olje, så det er jo ikke veldig bærekraftig. Til slutt tar det jo slutt. Og da mister vi arbeidsplassene igjen. Så man får arbeidsplasser en stund, da. Men det tar jo slutt, og da er det ikke så veldig bærekraftig over lengre tid.

I replikk 52 ser vi det første eksempelet på at scenario A vert problematisert: Olja kan ta slutt. I eit langsiktig perspektiv er dermed ikkje oljeutvinninga berekraftig, og arbeidsplassane vil forsvinne. Sett i høve til det resonnementet som er presentert til no, der det tydeleg har vorte argumentert for oljeutvinning, er det Eva ytrar ei innvending:

Innvending 1: $\quad$ (med mindre) olja tek slutt 
Like etter formulerer ei anna av jentene, Mary, heile to innvendingar. Sidan Eva hadde ordet er turist-temaet introdusert, og debattleiaren grip fatt i dette sporet og spør direkte om nokon ser eventuelle negative konsekvensar for turismen. Det gjer Mary:

<65>Mary: Fisken kan bli skremt bort, og turismen kan synke. Og det kan gå utover fisket.

Innvendingane Mary legg fram kan seiast å handle om to ulike aspekt som heng ganske tett saman, nemleg at oljeutvinning kan skade naturen og særleg fisket og at oljeutvinning (difor) kan svekkje turismen:

Innvending 2: $\quad$ (med mindre) oljeutvinning skadar naturen og særleg fisket

Innvending 3: (med mindre) oljeutvinning svekkjer turismen

Joe tenkjer annleis, og held via fleire replikkar fram at oljeutvinninga derimot vil ha positive ringverknader for turismen:

<74>Joe: Jeg vil tro det at hvis de slutter å komme hit på grunn av naturen, så vil de starte å komme hit på grunn av byen. Og hvis vi da øker kjøpesentre og butikker, sånne ting, så vil de heller komme hit for å være i byen, enn å se på naturen.

$<75>$ Forsker 1: Ja. Så kanskje turismen kommer likevel, fordi det blir et annerledes Vestvik.

Ifølgje Joe kan oljeutvinninga jamvel gje ein ny type turisme, ein meir urban turisme, og dette vert då enda eit belegg for hovudpåstand 1. Dette belegget kan openbert heimlast i at økonomisk vekst er eit gode (heimel 1), men vi kan 
her også inferere ein annan heimel, som vektlegg endring som noko positivt i seg sjølv (heimel 3):

\begin{tabular}{|l|l|}
\hline Hovudpåstand 1 & $\begin{array}{l}\text { Det bør bli full oljeutvinning i Lofoten- } \\
\text { området }\end{array}$ \\
\hline Belegg 5 & Oljeutvinning vil føre til ein ny type turisme \\
\hline Heimel 3 & Endring er eit gode \\
\hline
\end{tabular}

Tabell 5

Via Joes replikkar er ideen om eit kjøpesenter lansert, og det vekkjer eit stort engasjement hos elevane. Kjøpesenter-ideen kan seiast å ha to funksjonar i argumentasjonen. For det første er kjøpesenteret knytt til argumentasjonen rundt ny turisme, økonomisk vekst og endring, som det akkurat vart gjort greie for over. For det andre er kjøpesenter-ideen også knytt til lokalbefolkninga sine eigne behov, slik det særleg kjem fram i starten på Evas replikk under:

<105>Eva: Jeg synes i hvert fall at kjøpesenter ... vi burde få Ikea, for IkeaDet er veldig mange- Vi bruker i hvert fall å kjøre langt bare for å handle en sofa og møbler og sånt, og så kommer det kanskje turister hit, og vi får jo Ikea er veldig stort, så da får vi jo masse arbeidsplasser der. Jeg synes det er en bedre mulighet, å få Ikea.

Ut frå dette kan det etablerast enda eit belegg i resonnementet, nemleg belegg 6. Dette belegget er klart relatert til belegg 1 og 3 (arbeidsplassar, inntekter) og fungerer med same heimling (økonomisk vekst), men det fortener å setjast 
opp som separat belegg fordi kjøpesenter-ideen var noko elevane la så stor vekt på i argumentasjonen sin:

\begin{tabular}{|l|l|}
\hline Hovudpåstand 1 & $\begin{array}{l}\text { Det bør bli full oljeutvinning i Lofoten- } \\
\text { området }\end{array}$ \\
\hline Belegg 6 & $\begin{array}{l}\text { Oljeutvinning kan føre til ekspansjon av } \\
\text { Vestvik med kjøpesenter }\end{array}$ \\
\hline Heimel 1 & Økonomisk vekst er eit gode \\
\hline
\end{tabular}

Tabell 6

Fram mot første pause kjem det ikkje opp noko substansielt nytt i høve det resonnementet som er etablert, med unntak av at ei innvending til vert formulert, nemleg at oljeprisen kan gå ned:

<126>Anne: Det er liksom, at en negativ virkning kan være at vi tar penger, og at vi etter hvert finner ut at vi gjør ting enda bedre enn å bruke olje, og at det går ned i pris, sånn at - Og det kan jo gå utover oss, at det ikke var så positivt likevel.

<127>Forsker 1: Ja, oljeprisen kan gå ned, og så sier du at - hva slags effekt kan det ha?

$<128>$ Anne: At det tar, at det blir negativt, blir slutt, eller at det blir for dyrt for oss å produsere og sånt, at vi ikke får nok igjen. 
Innvending 4: $\quad$ (med mindre) oljeprisen fell

Vi har no følgd debatten i ganske stor detalj fram til første pause (replikk 37156), og det har late seg gjere å etablere eitt felles resonnement som alle dei siterte replikkane bidreg til. Det skal vise seg at dette resonnementet er det mest utbygde resonnementet i heile debatten. I resonnementet inngår seks belegg, tre heimlar og fire innvendingar. I sin heilskap ser dette resonnementet, som vi kallar resonnement A, slik ut:4

\begin{tabular}{|l|l|}
\hline Hovudpåstand & $\begin{array}{l}\text { Det bør bli full oljeutvinning i Lofoten- } \\
\text { området }\end{array}$ \\
\hline Belegg 1 & Oljeutvinning vil gje arbeidsplassar \\
\hline Belegg 2 & Oljeutvinning vil gje tilflytting \\
\hline Belegg 3 & Oljeutvinning vil gje inntekter \\
\hline Belegg 4 & Oljeutvinning vil føre til auka beredskap \\
mot oljeutslepp
\end{tabular}

${ }^{4}$ Det går fram av analysen over korleis belegg og heimlar er kopla saman i resonnement A.

K.M. R. Breivega 


\begin{tabular}{|c|c|}
\hline Belegg 6 & $\begin{array}{l}\text { Oljeutvinning kan føre til ekspansjon av } \\
\text { Vestvik med kjøpesenter }\end{array}$ \\
\hline Heimel 1 & Økonomisk vekst er eit gode \\
\hline Heimel 2 & Auka beredskap er eit gode \\
\hline Heimel 3 & Endring er eit gode \\
\hline Innvending 1 & (med mindre) olja tek slutt \\
\hline Innvending 2 & $\begin{array}{l}\text { (med mindre) oljeutvinning skadar naturen } \\
\text { og særleg fisket }\end{array}$ \\
\hline Innvending 3 & $\begin{array}{l}\text { (med mindre) oljeutvinning svekkjer } \\
\text { turismen }\end{array}$ \\
\hline Innvending 4 & (med mindre) oljeprisen fell \\
\hline
\end{tabular}

Tabell 7: Resonnement A

Er det så ikkje meir å seie om debatten resonnementsmessig? Jo, for det første er mot-argumentasjonen i resonnement A så omfattande at han må setjast opp som eit eige resonnement. I resonnement A er det heile fire innvendingar, og dei fungerer som belegg i eit alternativt resonnement. Hovudpåstanden i 
resonnement B kan formulerast slik: «Oljeutvinning er risikabelt». Nedanfor er dette resonnementet sett opp med belegg, heimlar og innvendingar.

Hovudpåstanden i resonnement B ligg ikkje like nær formuleringa av eit scenario slik vi fann i resonnement $\mathrm{A}$, der hovudpåstanden var nesten identisk med scenario A («Det skal borast for fullt etter olje utanfor Lofoten»). Elevane som står for mot-argumentasjonen etablerer altså ikkje ein hovudpåstand som like tydeleg byggjer på scenario B eller C (kompromiss-løysing eller nei til oljeutvinning), men dei uttrykkjer alle klart skepsis til oljeutvinninga.

\begin{tabular}{|c|c|}
\hline Hovudpåstand & Oljeutvinning er riskabelt \\
\hline Belegg 1 & Olja kan ta slutt \\
\hline Belegg 2 & $\begin{array}{l}\text { Oljeutvinning vil skade naturen og særleg } \\
\text { fisket }\end{array}$ \\
\hline Belegg 3 & $\begin{array}{l}\text { Oljeutvinning vil svekkje turismen i } \\
\text { Lofoten-området }\end{array}$ \\
\hline Belegg 4 & Oljeprisen kan falle \\
\hline Heimel 1 & $\begin{array}{l}\text { Lofoten-området må sikrast } \\
\text { næringsinntekter }\end{array}$ \\
\hline Heimel 2 & Miljøet må vernast \\
\hline
\end{tabular}

K.M. R. Breivega 


\begin{tabular}{|l|l|}
\hline Heimel 3 & $\begin{array}{l}\text { Turistane kjem på grunn av naturen og } \\
\text { fisket }\end{array}$ \\
\hline Innvending 1 & $\begin{array}{l}\text { (med mindre) Lofoten-området kan sikrast } \\
\text { inntekter på andre måtar }\end{array}$ \\
\hline Innvending 2 & $\begin{array}{l}\text { (med mindre) oljeutvinninga i dag er heilt } \\
\text { trygg }\end{array}$ \\
\hline Innvending 3 & $\begin{array}{l}\text { (med mindre) turistane kjem av andre } \\
\text { grunnar }\end{array}$ \\
\hline
\end{tabular}

Tabell 8: Resonnement B, mot-argumentasjonen

Det som skjer seinare i debatten, etter første pause, er at diskusjonen vert meir fragmentarisk i den forstand at det er vanskelegare å innplassere det elevane seier i store, utbygde resonnement à la resonnement A og B. Dette vil ikkje nødvendigvis seie at elevane argumenterer dårlegare. Via resonnement A og B er på eit vis alle sentrale påstandar alt formulerte - alle ballane er alt i lufta - og elevane arbeider vidare med dette stoffet på den måten at belegg, heimlar og innvendingar i dei to resonnementa vert gjentekne, reformulerte og utdjupa. Karakteristisk for debatten etter første pause er også at debattleiaren si rolle vert meir tilbaketrekt. Elevane er meir sjølvgåande, og «Forsker 1» fungerer stort sett som ordstyrar.

Eit interessant eksempel på gjenbruk av ein komponent i resonnement A finn vi når eleven Roy tek ordet første gong etter pause: 
$<178>$ Roy: Jeg mener jo det personlig, at forandring er det beste for Vestvik akkurat nå. Vi trenger å ta et par sjanser, for nå har vi levd på fisk, og tørrfisk, og turistene, i mange, mange år - og det at vi går inn for å prøve, i hvert fall å prøve å bli en storby - det er en god ting. [...]

Det Roy formulerer her, er heimel 3 i resonnement A (Endring er eit gode). Denne heimelen var inferert $\mathrm{i}$ analysen over, han var nemleg ikkje eksplisitt uttrykt i diskusjonen før pause og fungerte som ein underliggjande premiss. Men her vert altså heimelen tydeleg formulert. I replikkane som følgjer svarer fleire av elevane på Roys litt spissformulerte ytring, og det dei i praksis gjer, er gjenbruke mot-argumentasjonen i resonnement A eller fleire av belegga i resonnement B, alt etter kva resonnement ein legg til grunn.

Eit anna eksempel på gjenbruk finn vi i sekvensen fram mot andre pause (replikk 234-276), der elevane mellom anna diskuterer om det er andre næringar ein kan satse på i regionen for å sikre økonomisk vekst og turisttilstrøyming. Dei arbeider då vidare med stoff både frå resonnement A og B. Dei ser føre seg meir satsing på fiskemat, surfing og klatring, restaurantar, krigsmuseum, flyplass og universitet.

I den siste tredjedelen av debatten krinsar debatten i større grad enn tidlegare rundt det ein kanskje skulle tru ville vere eit hovudtema i Lofoten-debatten, nemleg faren for forureining og korleis risikoen kan reduserast. I denne sekvensen utdjupar elevane mot-argumentasjonen i resonnement A (særleg innvending 2) og belegg 2 og heimel 2 i resonnement B.

Oppsummert har då denne analysen vist at elevane i den første delen av debatten saman etablerer eit utbygd resonnement, nemleg resonnement A, med utgangspunkt i scenario A (at det bør bli full oljeutvinning i Lofotenområdet). Resonnement A inneheld dessutan ein omfattande motargumentasjon (fire innvendingar), med særleg vekt på konsekvensar for 
turismen og naturen. Mot-argumentasjonen utgjer eit eige, alternativt resonnement, nemleg resonnement B. I resonnement B finn vi argumenta som typisk kan knytast til scenario B og C (kompromiss-løysing eller nei til oljeboring), men ikkje på den måten at sjølve hovudpåstandsformuleringa er nesten identisk med formuleringa av eitt av scenarioa, slik tilfellet er for scenario A og resonnement A. Det som vidare karakteriserer debatten etter første pause, er at belegg, heimlar og innvendingar i resonnement A og B vert gjenbrukte, reformulerte og utdjupa, men utan at dette munnar ut i nye, utbygde resonnement.

\section{Avsluttande drøfting}

Korleis argumenterer elevane?

Det overordna forskingsspørsmålet for denne artikkelen er kva retorisk kompetanse elevane syner i form av å byggje resonnement saman. Sentrale tema i debatten var m.a. arbeidsplassar, turisme, torskefiske og kjøpesenter. Og desse temaa vart ikkje presenterte i lause assosiasjonsrekkjer. Debatten framstod koherent. Analysen syner at debatten let seg rekonstruere i form av eitt felles hovudresonnement (resonnement A) som også inneheld ein tydeleg mot-argumentasjon (resonnement B). Analyseresultata tyder dermed at elevane meistrar å resonnere saman, at dei må ha ei grunnleggjande forståing av korleis ulike påstandar om verda relaterer seg til kvarandre i ein resonnementstruktur.

Elevane klarer likevel ikkje dette heilt av seg sjølve. I eit munnleg-didaktisk perspektiv skal det framhevast at debatten var godt førebudd gjennom scenariobaserte gruppearbeid (Pereira 2001). Via gruppearbeida hadde elevane ein trygg base dei kunne gå ut frå. Når Tom vart utfordra aller først i debatten, var det gruppa sine konklusjonar han delte. Vidare i debatten snakka mange av elevane meir og meir på eigne vegner. At dei meistra å gå inn 
i debatt på denne måten, kan henge saman med at dei fekk diskutere eit autentisk, kontroversielt og komplekst tema som vedkom dei personleg (Hess 2009). Dessutan spelte debattleiaren ei viktig rolle. Særleg i starten av debatten, fram mot det første friminuttet, var debattleiaren tydeleg til stades. Ho støtta elevane ved å gjenta og anerkjenne det dei sa, men stilte også konkrete spørsmål, bad dei ofte utdjupe og etterlyste ved mange høve motargumentasjon. Etter den første pausen vart debattleiaren meir tilbaketrekt. Dette kan tolkast som at elevane hadde vortne varme i trøya og ikkje lenger trong den støtta ho representerte i starten av debatten.

I elevane sin argumentasjon kan vi i og for seg kjenne att dei fleste argumenta frå det offentlege ordskiftet om Lofoten, slik desse vart refererte tidlegare i denne artikkelen. Sentrale belegg og heimlar for oljeutvinning er, som vi har sett, arbeidsplassar, tilflytting og generell økonomisk vekst. Motargumentasjonen handlar om oljeutvinninga ikkje nødvendigvis vil vere så økonomisk berekraftig på sikt, om konsekvensar for naturen, og då særleg fisket, og ikkje minst om eventuelle konsekvensar for turismen. Det er også verd å merke seg at mange av dei same emna eller argumenta dukkar opp i begge resonnementa. Turismen inngår tydeleg i mot-argumentasjonen, men vert, som vi har sett over, også kopla til argumentasjonen for oljeutvinning. Vidare har også resonnement B ein heimel for økonomisk vekst (jamfør «Lofoten må sikrast næringsinntekter»). Miljø- og naturverntankegangen i mot-argumentasjonen er nemleg i stor grad relatert til den næringsinteressa turismen representerer. Både resonnement A og B har slik ei tydeleg heimling i behovet for økonomisk vekst.

Når resonnement A er å sjå som det sentrale resonnementet, skal dette ikkje oppfattast slik at alle elevane som deltek er for oljeutvinning eller scenario A. Som vi har sett, er mange av elevane (og særleg jentene) målberarar av motargumentasjonen til resonnement A. At resonnement A er å sjå som hovudresonnementet, kan reformulerast slik: 
Hovudpåstanden Tom formulerer i replikk 38 fungerer på ein vellykka måte som eit utgangspunkt for diskusjonen, som ein påstand dei andre elevane på ulike måtar responderer på. Formulert på ein annan måte, byggjer elevane gjensidig og kumulativt opp dette resonnementet (jf. Alexander 2005). Slik Lofoten-debatten utvikla seg, handla han ikkje om å kome fram til éin klar konklusjon, men snarare om å utforske og formulere argumentasjon rundt eit sakskompleks. Slik var debatten eit godt eksempel på den typen samhandling dialogisk klasseromsundervisning ønskjer å fremje.

\section{Toulmin-modellen som analysereiskap}

Eit anna siktemål ved denne artikkelen var å diskutere kva potensial Toulminmodellen har som analysereiskap i munnleg-didaktisk forsking. Mange ser det slik at Toulmin-modellen er for produktorientert, statisk og monologisk, og at han må supplerast med analytiske reiskap som i større grad får fram dialogiske og pragmatiske sider ved i kommunikasjonen. Analysen som er presentert over, har vonleg synt det ikkje treng eksistere noko motsetnadstilhøve mellom ei resonnementstilnærming til elevars argumentasjonskompetanse og eit dialogisk perspektiv på undervisning og språkbruk. Det er likevel nokre punkt som kan kommenterast.

For at modellen skulle fungere i møte med dialogisk argumentasjon, er det for det første gjort visse tilpassingar i den analytiske tilnærminga. Desse tilpassingane har først og fremst handla om å utnytte det dialektiske potensialet som ligg i komponenten innvending.

Ein Toulmin-analyse får på ein tydeleg og ryddig måte fram kva påstandar som er fremja i ein diskusjon og korleis dei interagerer i ein logisk strukturert resonnementstruktur, men i eit retorisk perspektiv kan denne styrken ved modellen også sjåast som ein veikskap. Sjølv om Toulmin-modellen synest å inngå i den retoriske «verktøykassa», slik ho vert presentert f.eks. hos 
Jørgensen \& Villadsen 2009 og Kjeldsen 2014, har modellen utan tvil sitt utspring eit proposisjonslogisk syn på argumentasjon. Somme vil då meine at analysane kan framstå mekaniske og at dei tvingar språkbruken inn i ei normativ logisk form, i staden for å f.eks. å ta utgangspunkt i «kollektivt utvecklade diskursive vanor», slik Söderberg definerer topos-omgrepet (Söderberg 2017, s. 41). Ein topologisk basert argumentasjonsanalyse vil vere meir forankra i den spesifikke språkbruken og dei argumenta og argumentasjonsmønstra ein faktisk finn og tilsvarande mindre oppteken av å få argumentasjonen til å passe inn i eit gjeve, overordna mønster (sjå også Høisæter under utgjeving).

Styrken ved Toulmin-modellen er likevel at han så tydeleg får fram korleis argumentasjonen rundt ein hovudpåstand (i Lofoten-debatten i form av politiske handlingsalternativ) er bygd opp. Resonnementanalysar à la dei som er presenterte her kunne ein også bygd vidare på i eit undervisningsopplegg. Ein kunne analysert diskusjonar elevane sjølve hadde gjennomført (som her) eller annan debatt. Mellom anna kunne ein då ha sett på dynamikken i resonnementsstrukturar, korleis ein og same påstand eller tematikk kan ha fleire funksjonar, slik turismen og heimlinga for økonomiske omsyn er gode eksempel på i Lofoten-debatten. Dette kan gje elevar ei djupare forståing av kva det vil seie «å delta diskusjoner med begrunnede meninger og saklig argumentasjon» (Kunnskapsdepartementet 2006), noko som også vil fremje demokratisk praksis og danning - både i elevrolla og på sikt. 


\section{Referansar:}

Aksnes, L.M. (2016). Om muntlighet som fagfelt. I Kverndokken, K. (red.), 101 måter å fremme muntlige ferdigheter på. Om muntlig kompetanse og muntlighetsdidaktikk (s. 15-34). Bergen: Fagbokforlaget.

Alexander, R. (2005). Towards Dialogic Teaching. Rethinking Classroom Talk. Cambridge: Dialogos.

Bakhtin, M.M. (1998). Spørsmålet om talegenrane. Omsett og med etterord av R.T. Slaattelid. Bergen: Ariadne forlag.

Bakken, J. (2014). Retorikk i skolen. 2. utgåva. Oslo: Universitetsforlaget.

Berge, K.L. \& Stray, J.H. (2012). Demokratisk medborgerskap i skolen. Bergen: Fagbokforlaget.

Bjørhusdal, E. (2014). Mellom nøytralitet og språksikring: Norsk offentleg språkpolitikk 1885-2005. Phd-avhandling. Det utdanningsvitskaplege fakultetet. Oslo: Universitetet i Oslo.

Breivega, K.M.R, Hauge, K.H., Johnsen-Høines, M. \& Rangnes, T.E. (2016). Klasseromsdebatt som danningsarena. Norsklæraren, 4, s. 45-52.

Breivega, K.M.R. (under utgjeving). Elevars diskursive posisjonering i debatt. I K.M.R. Breivega \& T.E. Rangnes (red.), Demokratisk danning i skolen. Empiriske studier. Bergen: Universitetsforlaget.

Brodersen, R., Bråten, F. J., Reiersgaard, A., Slethei, K. \& Ågotnes, K. (2007). Tekstens autoritet. Tekstanalyse og skriving i akademia. Bergen: Universitetsforlaget. 
Brumark, Å. (2011). Medborgarfostran och elevinflytande i skolans offentlighet. Rhetorica Scandinavica 59, s. 54-68.

Børresen, B. (2016). Samtalen i klasserommet. Samtale og læring. I Kverndokken, K. (red.), 101 måter å fremme muntlige ferdigheter på. Om muntlig kompetanse og muntlighetsdidaktikk (s. 89-101). Bergen: Fagbokforlaget.

Dysthe, O. (1995). Det flerstemmige klasserommet. Oslo: Ad Notam Forlag.

Englund, T. (2007). Skola för deliberative kommunikation. I T. Englund (red.). Utbildning og kommunikation. Deliberativa samtal som möjlighet (s. 153-168). Göteborg: Bokförlaget Diadolos.

van Eemeren, F. H., Garssen, B., Krabbe, E.C.W., Henkemans, A.F.S., Verheij, B. \& Wagemans, J.H.M. (2014). Toulmin's Model of Argumentation. I F. H. van Eemeren, B. Garssen, E.C.W. Krabbe, A.F.S. Henkemans, B. Verheij \& J.H.M. Wagemans, Handbook of Argumentation Theory (s. 203-256). Dordrecht mfl.: Springer.

Grepstad, O. (1997). Det litterære skattkammer. Sakprosaens teori og retorikk. Oslo: Samlaget.

Hertzberg, F. (2016). Muntlighet i norskfaget. Hvor er vi nå? Norsklæraren, 2, s. $23-37$.

Hess, D. E. (2009). Controversy in the Classroom. The Democratic Power of Discussion. New York \& London: Routledge.

Iversen, L.L. (2014). Uenighetsfellesskap. Blikk på demokratisk samhandling. Oslo: Universitetsforlaget. 
Høisæter, S.M. (under utgjeving). Med standpunkt i det kjente. Staden som topos i ungdomskuleelevars argumentasjon. I K.M.R. Breivega \& T.E. Rangnes (red.), Demokratisk danning i skolen. Empiriske studier. Bergen:

Universitetsforlaget.

Jørgensen, C. \& Villadsen, L. (red.) (2009). Retorik. Teori og praksis.

Fredriksberg: Samfundslitteratur.

Jørgensen, C. \& Onsberg, M. (2011). Praktisk argumentation. 3. utgåva. Valby: Nyt Teknisk Forlag.

Kjeldsen, J. E. (2014). Retorikk i vår tid. En innføring i moderne retorisk teori. Bergen: Spartacus.

Kunnskapsdepartementet (2006). Kunnskapsløftet. Oslo. Henta frå: https://www.udir.no/laring-og-trivsel/lareplanverket/

Myklebust, H. \& Høisæter, S.M. (2018). Written Argumentation for Different Audiences. A Study of Addressivity in Argumentative Student Texts. Acta Didactica Norge, 12/3. DOI: http://dx.doi.org/10.5617/adno.4727

Nielsen, J. A. (2013). Dialectical Features of Students' Argumentation: A Critical Review of Argumentation Studies in Science Education. Research in Science Education 43, s. 371-393.

Pereira, A.G. (2001). The Visions Project at the JRC. Rapport frå Institute for the Protection and Security of the Citizen. European Commission. Joint Research Centre.

https://cordis.europa.eu/publication/rcn/200214623 en.html

Ryggvik, G. \& Sander, G. (2017). Striden om oljeboring i nord i Store Norske Leksikon. https://snl.no/Striden om oljeboring i Nord 
Sande, A. (2013). Slaget om Lofoten - Olje eller verdensarv? Oslo:

Akademika forlag.

Simosi, M. (2003). Using Toulmin's Framework for the Analysis of Everyday Argumentation: Some Methodological Considerations. Argumentation, s. 187202.

Skaftun, A. (2009) Dialogen som paradigme? Norlit, 12, 137-152. Henta frå http://www-hum.no/nordlit/12/og_Skaftun.pdf

Svenkerud, S. F., Klette, K. \& Hertzberg, F. (2012). Opplæring i muntlige ferdigheter. Nordic Studies in Education, Band 32, s. 35-49.

Söderberg, M. W. (2017). Aristoteles retoriska toposlära. En verktygsrepertoar för fronesis. Södertörn högskola: Södertörn retoriska studier 4.

Toulmin, S. E. (2003) [1958]. The Uses of Argument. Updated Edition. Cambridge: Cambridge University Press.

Utdanningsdirektoratet (2017). Overordnet del av læreplanverket. https://www.udir.no/laring-og-trivsel/lareplanverket/overordnet-del/

Øgreid, A. K. (2017). Bruk av modelltekster i arbeidet med skriftlig argumentasjon. En studie av åttendeklasseelevers skriving i RLE-faget. I N.G. Garmann \& Å.M. Ommundsen (red.), Danne og utdanne. Litteratur, språk og samtale, s. 199-226. Oslo: Novus forlag. 